This is a self-archiving document (manuscript version):

Water management in novel direct membrane deposition fuel cells under low humidification

By: Breitwieser, Matthias; Moroni, Riko; Schock, Jonathan; Schulz, Michael; Schillinger, Burkhard; Pfeiffer, Franz; Zengerle, Roland;

Thiele, Simon

Published in: International Journal of Hydrogen Energy

Volume 41, Issue 26, 13 July 2016, Pages 11412-11417 (Please be aware: Page numbering in this manuscript can be different to published version!)

Publisher: Elsevier | Year: 2016

DOI: 10.1016/j.jijydene.2016.05.018

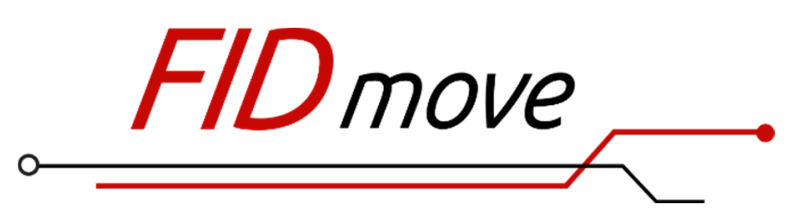

Brought to you by the Scientific Information Service for Mobility and Transport Research

Fachinformationsdienst Mobilitäts- und Verkehrsforschung

Website: www.fid-move.de

Repository: publish.fid-move.de

Contact: publish@fid-move.de

(C) 2020. This manuscript version is made available under the CC-BYNC-ND 4.0 license.

http://creativecommons.org/licenses/by-nc-nd/4.0/ 


\title{
Water management in novel direct membrane deposition fuel cells under low humidification
}

\author{
M. Breitwieser ${ }^{a, e, *}$, R. Moroni ${ }^{a}$, J. Schock ${ }^{b}$, M. Schulz ${ }^{c}$, B. Schillinger ${ }^{c}$, \\ F. Pfeiffer ${ }^{b}$, R. Zengerle ${ }^{a, e}$, S. Thiele ${ }^{a, d, e}$ \\ ${ }^{a}$ Laboratory for MEMS Applications, IMTEK, Department of Microsystems Engineering, University of Freiburg, \\ Germany \\ ${ }^{\mathrm{b}}$ Lehrstuhl für Biomedizinische Physik, Physik-Department \& Institut für Medizintechnik, Technische Universität \\ München, Garching, Germany \\ ${ }^{c}$ Heinz Maier-Leibnitz Zentrum (MLZ), Technische Universität München, Garching, Germany \\ d FIT, University of Freiburg, Georges-Köhler-Allee 105, 79110 Freiburg, Germany \\ e Hahn-Schickard-Gesellschaft für angewandte Forschung e.V, Wilhelm-Schickard Straße 10, \\ 78052 Villingen-Schwenningen, Germany
}

\begin{abstract}
A B S T R A C T
Polymer electrolyte membrane fuel cells (PEMFCs) fabricated by direct membrane deposition (DMD) were shown to work even at dry conditions without significant deterioration of the membrane resistance. Here, in situ neutron radiography is used to investigate the water management in those fuel cells to uncover the phenomena that lead to the robust operation under low humidification. A constant level of humidification within the membrane electrode assembly (MEA) of a DMD fuel cell is observed even under dry anode operation and $15 \%$ relative humidity on the cathode side. This proves a pronounced back diffusion of generated water from the cathode side to the anode side through the thin deposited membrane layer. Over the entire range of polarization curves a very high similarity of the water evolution in anode and cathode flow fields is found in spite of different humidification levels. It is shown that the power density of directly deposited membranes in contrast to a $50 \mu \mathrm{m}$ thick $\mathrm{N}-112$ membrane is only marginally affected by dry operation conditions. Water profiles in through-plane direction of the MEA reveal that the water content in the DMD fuel cell remains steady even at high current densities. This is in contrast to the N-112 reference fuel cell which shows a strong increase in membrane resistance and a reduced MEA water content with raising current densities. Thus this new MEA fabrication technique has a promising perspective, since dry operation conditions are highly requested in order to reduce fuel cell system costs.
\end{abstract}

Keywords:

PEMFCs

Direct membrane deposition

Neutron radiography

Water management

Back diffusion

\footnotetext{
* Corresponding author. Laboratory for MEMS Applications, IMTEK, Department of Microsystems Engineering, University of Freiburg, Germany. Tel.: +49 76120395086.

E-mail address: matthias.breitwieser@imtek.de (M. Breitwieser).

http://dx.doi.org/10.1016/j.ijhydene.2016.05.018
} 


\section{Introduction}

Direct membrane deposition (DMD) is a novel MEA fabrication method, where the membrane layer of a PEMFC is directly deposited onto its anode and cathode gas diffusion electrodes [1]. This MEA fabrication method enables very low membrane resistances below $13 \mathrm{~m} \Omega \mathrm{cm}^{2}$ and therefore high fuel cell power densities beyond $4.0 \mathrm{~W} / \mathrm{cm}^{2}$ with $\mathrm{H}_{2} / \mathrm{O}_{2}$ as feed gases at $300 \mathrm{kPa}_{\mathrm{abs}}$ and beyond $1.3 \mathrm{~W} / \mathrm{cm}^{2}$ under stoichiometric 1.2/2.0 $\mathrm{H}_{2}$ /air operation at $300 \mathrm{kPa}_{\text {abs. }}$. The high performance was linked to a very low membrane thickness of about $12 \mu \mathrm{m}$ and an improved interface between catalyst layer and the membrane itself [1,2]. Despite the high power densities another significant difference was identified compared to conventionally cast membranes: The cell polarization measurements in the work of Klingele et al. [1] reveal that the ionic resistance increased only slightly at low humidification. Even when the humidification of the reactant gases was reduced to zero, the maximum cell power dropped only by about $10 \%$. This finding diverged from the known characteristics of fuel cells with conventional Nafion ${ }^{\circledR}$ membranes [3-5] and is therefore of high interest for further investigation. Even though dry operation of fuel cells with Nafion ${ }^{\circledR}$ membranes was reported in literature before, a more significant drop in cell power density between 20 and $40 \%$ was usually observed [3]. To enable dry fuel cell operation by self-humidification, complex composite structures such as thin Nafion/Pt/SiO 2 [6], Nafion/Pt-clay [7] or sulfonated pol$\mathrm{y}$ (ether ether ketone) (SPEEK)/Pt-Zirconia [8] composite membranes have been proposed. Klingele et al. demonstrated the operation of a directly deposited pure Nafion membrane without any external humidification. This finding was attributed to a strongly facilitated back diffusion of water from the cathode to the anode side through the about $12 \mu \mathrm{m}$ thin directly deposited membrane. This back diffusion was believed to humidify the membrane sufficiently even under dry conditions and at high current densities. To prove this hypothesis, this work presents in situ neutron imaging of fuel cell operation with dry anode feed gas to analyse the amount of water in the MEA under low humidification.

Neutron imaging is well suited to investigate water evolution and has been widely employed in in situ fuel cell experiments [9-14]. The strong attenuation of neutrons in water enables imaging liquid water evolution within a fuel cell in operation. The neutron-based analysis of various fuel cell operation conditions [15], flow field designs [16] or gas diffusion materials [17] was reported in literature previously using conventionally cast membranes. Water back diffusion, even in a thick Nafion ${ }^{\circledR} \mathrm{N}-117$ membrane, was recently investigated by Iranzo et al. [18]. These studies motivate the use of neutron imaging for the characterization of the water distribution in DMD fuel cells.

\section{In situ neutron radiography}

In situ neutron radiography experiments were performed at the neutron beamline "ANTARES" at Heinz-Maier-Leibnitz Zentrum (MLZ) at the Technische Universität München 
(TUM). The setup was described in detail by Calzada et al. [19] and is shown schematically in Fig. 1a). The neutron beam coming through a pinhole from the reactor can be used for imaging purposes in the two separate beam chambers. The fuel cell, shown in Fig. 1b), was located in the first measurement chamber (blue area in Fig. 1a). We used a specifically designed aluminium fuel cell fixture (see Fig. 1b). This ensured sufficient transparency of the PEMFC for the beam. The fuel cell was operated from outside the beam chamber via $5 \mathrm{~m}$ long heated gas lines. This ensured that the sensitive electronics of the fuel cell tester could be placed outside the beam chamber and thus were not damaged during the experiments. For the neutron experiments, the fuel cell was placed in-plane with the beam direction to observe the dynamic water evolution inside its anode and cathode flow channels separately (Fig. 1b). A $18 \mathrm{~mm}$ pinhole was used, resulting in an L/D ratio of 500 at the sample position. The effective pixel size was about $27 \mu \mathrm{m}$ and was determined experimentally from the known geometry of the micro-milled gas flow channels of $500 \mu \mathrm{m}$ width. For the neutron images during polarization measurements shown in Fig. 3, an integration time of $60 \mathrm{~s}$ was chosen to enhance water sensitivity. To track the water evolution as dynamically as possible during a steady potential, an integration time of $5 \mathrm{~s}$ was chosen. Due to this short integration time, the recorded radiographies at steady state conditions were rebinned to a resolution of $137 \mu \mathrm{m}$ in order to achieve a sufficient signal-to-noise ratio as described elsewhere [20].

To extract the actual water generation in the flow channels, the neutron absorption of the dry fuel cell was taken as reference. The water profiles shown in Figs. 2 and 3 were generated by summarizing the water signal in the fuel cell. The offset of the CCD detector (Andor, Ikon L, $2048 \times 2048$ pixels) was eliminated by subtraction of a dark image with closed beam shutter. Gamma spots were corrected in the postprocessing. Before each in situ experiment a neutron image under OCV conditions was recorded to exclude a falsification by residual water from previous operation.

\section{Sample preparation and fuel cell operation}

To fabricate the DMD fuel cell, one layer of Nafion ${ }^{\circledR}$ dispersion (1 part Nafion ${ }^{\circledR}$ D2020 mixed with two parts 1-propanol) was inkjet-printed onto $5 \mathrm{~cm}^{2}$ anode and cathode gas diffusion electrodes (GDEs) purchased from Paxitech SAS. The GDEs were loaded with $0.5 \mathrm{mg}_{\mathrm{Pt}} / \mathrm{cm}^{2}$ at $70 \% \mathrm{Pt} / \mathrm{C}$ and contained Nafion ${ }^{\circledR}$ as ionomer. The thickness of each catalyst layer was about $10 \mu \mathrm{m}$ (measured by scanning microscope imaging on MEA cross-sections), the thickness of each gas diffusion layer (in the compressed state) was approximately $200 \mu \mathrm{m}$, according to the manufacturer. The fuel cell was assembled by placing the two GDEs covered by the printed membrane layers face to face. A $50 \mu \mathrm{m}$ thin PTFE foil was used as subgasket to prevent parasitic currents and gas crossover occurring at the edges of the GDEs. The subgasket reduced the active fuel cell area to $4 \mathrm{~cm}^{2}$. The fuel cell (shown in Fig. 1 b) was tightened with a torque of $1 \mathrm{Nm}$. A detailed description of the sample preparation including the printing process was published previously [1,2]. As reference, we used an N-112 Nafion ${ }^{\circledR}$ membrane, coated with catalyst layers of identical Pt loading 

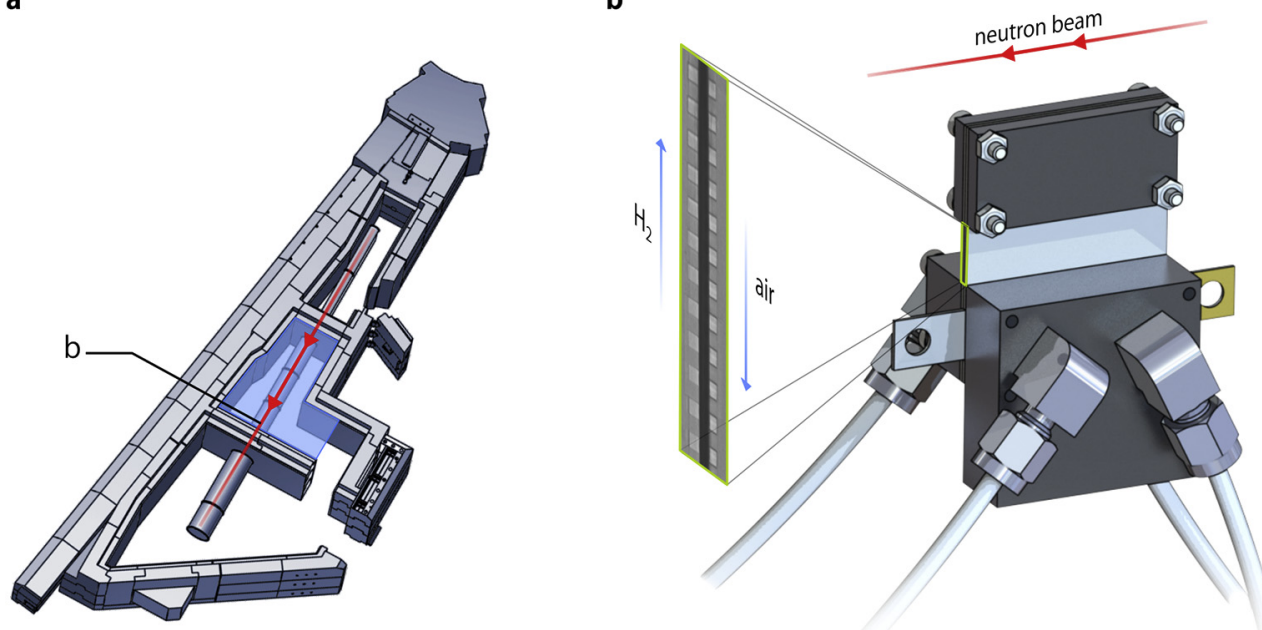

Fig. 1 - Schematic of the ANTARES setup at FRM-II (a). The neutron beam exits the reactor and passes through two measurement chambers. The fuel cell (b) is located in the first measurement chamber (blue shaded area in a). The fuel cell is operated with opposing feed gas flows from outside the beam chamber. The fuel cell is placed in-plane in the beam direction to analyse water evolution separately in anode and cathode flow channels. (For interpretation of the references to colour in this figure legend, the reader is referred to the web version of this article.)
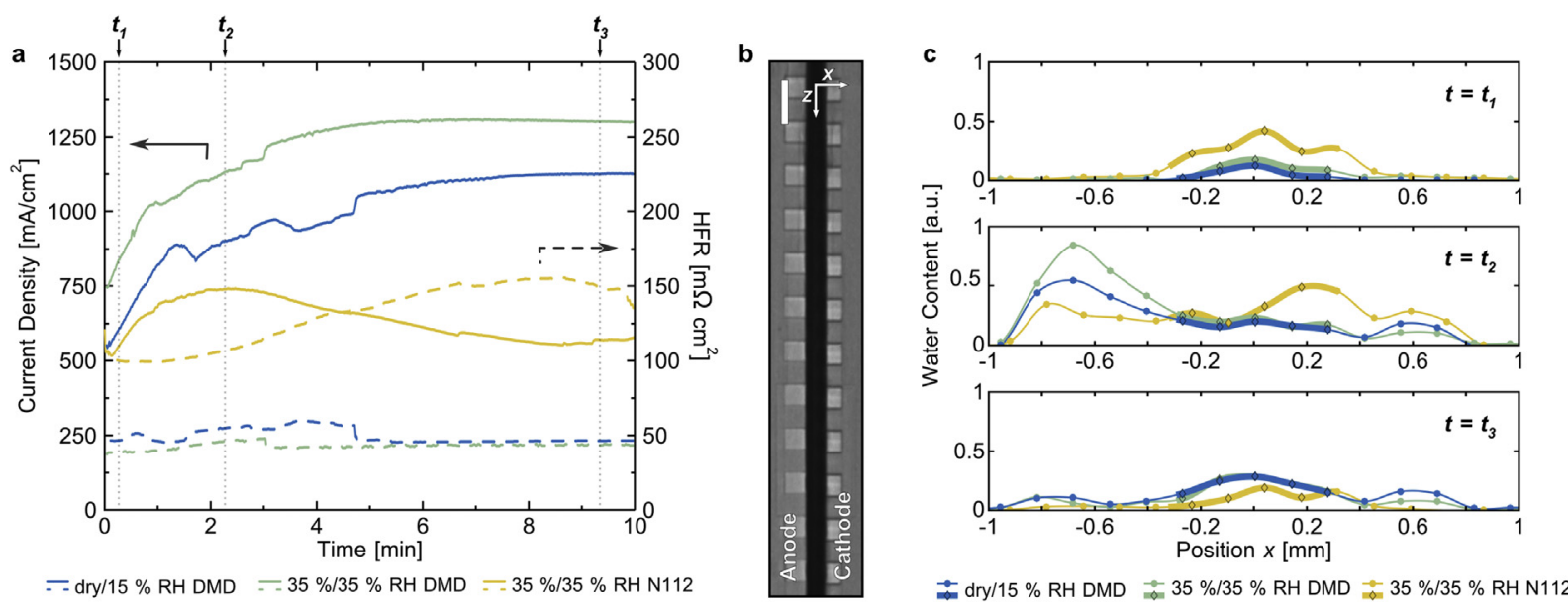

Fig. 2 - In a), the evolution of current density (left) and high frequency resistance (right) over time is plotted for the 35\%/35\% DMD fuel cell (green), the dry/15\% DMD fuel cell (blue) and the 35\%/35\% N-112 reference cell (yellow) at a fixed cell voltage of $0.5 \mathrm{~V}$. The vertical lines indicate the different points in time $\left(t_{1}=20 \mathrm{~s}, t_{2}=140 \mathrm{~s}, t_{3}=560 \mathrm{~s}\right)$ of the image acquisition. The orientation of the fuel cell is indicated in the neutron radiography of the dry cell in b). The scale bar corresponds to $1 \mathrm{~mm}$. c) Shows the corresponding water profiles as a function of the position within the MEA between anode (left side) and cathode flow field (right side) at different times for each cell. The operation conditions were: $70{ }^{\circ} \mathrm{C}, 1.5 / 2.5 \mathrm{H}_{2} /$ air, atmospheric pressure. (For interpretation of the references to colour in this figure legend, the reader is referred to the web version of this article.) 
and stacked between the same gas diffusion media (Paxitech SAS).

For the characterization of the DMD and the reference fuel cell, a Scribner 850e fuel cell testing system was used. Polarization data was recorded by sweeping the current from high to low voltages. The data for steady state measurement was obtained by applying a fixed potential of $0.5 \mathrm{~V}$ for $10 \mathrm{~min}$. The high frequency resistance (HFR) was measured in situ at a fixed frequency of $3.2 \mathrm{kHz}$ by a frequency response analyser

which is integrated into the Scribner 850e system. The HFR corresponds to the series resistance of the fuel cell and its main contributions are the ionic membrane resistance and the interface resistance between membrane and catalyst layer ionomer [13]. The fuel cell was heated to $70{ }^{\circ} \mathrm{C}$ whereas the relative humidity (RH) was adjusted to dry/15\% (anode/cathode) and $35 \% / 35 \%$. Each state of humidification was held for at least $3 \mathrm{~h}$ in order to avoid any artifacts due to remaining humidity from prior measurements and to fully equilibrate the
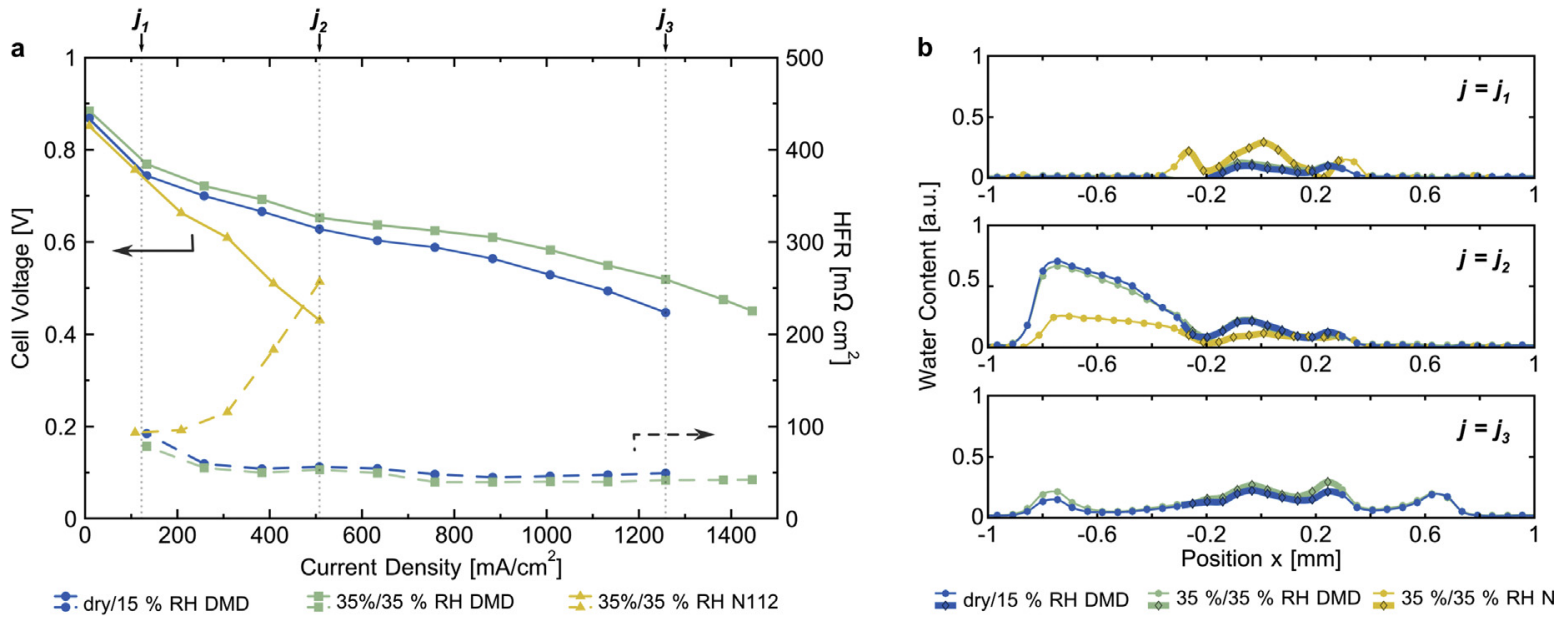

$\Rightarrow \mathrm{dry} / 15 \% \mathrm{RH}$ DMD $\Rightarrow 35 \% / 35 \% \mathrm{RH}$ DMD $\Rightarrow 35 \% / 35 \% \mathrm{RH}$ N112

Fig. 3 - In a) polarization data and HFR measurements of the 35\%/35\% DMD fuel cell (green), the dry/15\% DMD fuel cell (blue), and the 35\%/35\% N-112 reference cell (yellow) are shown. In b) the averaged corresponding water profiles are shown at different current densities of $125 \mathrm{~mA} / \mathrm{cm}^{2}, 500 \mathrm{~mA} / \mathrm{cm}^{2}$ and $1250 \mathrm{~mA} / \mathrm{cm}^{2}$. The operation conditions were: $70{ }^{\circ} \mathrm{C}, 1.5 / 2.5 \mathrm{H}_{2} /$ air, atmospheric pressure. (For interpretation of the references to colour in this figure legend, the reader is referred to the web version of this article.) 
fuel cells. Prior to the dry $/ 15 \%$ RH measurement the fuel cell was kept at $70^{\circ} \mathrm{C}$ and was purged with dry $\mathrm{N}_{2}$ gas for $15 \mathrm{~h}$ to exclude falsifications due to remaining anode humidification. In Ref. [1], the DMD fuel cell was operated under entirely dry conditions (anode and cathode side) at $300 / 300 \mathrm{kPa}_{\text {abs. }}$. In this work, we operate a DMD fuel cell with dry anode and a minor level of cathode humidification of $15 \% \mathrm{RH}$ even in ambient conditions without artificial pressurization. As depicted in Fig. 1b), an opposing stoichiometric reactant flow of $1.5 / 2.5 \mathrm{H}_{2}$ / air was applied to the fuel cell.

\section{Results and discussion}

Two experiments were performed to investigate the diverging water management in a DMD fuel cell compared to a commercial Nafion ${ }^{\circledR} \mathrm{N}-112$ CCM fuel cell:

In the first experiment the dynamics of water evolution from application of a voltage step to steady state condition was investigated. A fixed potential of $0.5 \mathrm{~V}$ was applied to the fuel cell for $10 \mathrm{~min}$ and water evolution over time was examined (Fig. 2). The generally long time until the fuel cell converges towards steady-state condition after the high voltage step to $0.5 \mathrm{~V}$ was attributed to the configuration of the test setup: Due to the $5 \mathrm{~m}$ long gas lines and moderate stoichiometric gas flow the stabilization of the current density took several minutes. In situ neutron radiographies with $5 \mathrm{~s}$ integration time were recorded continuously during the current density measurement. This enabled dynamic observation of water formation in the fuel cells. Since current density and HFR was logged with a precision of 1 s during the 10 min steady state potential, water management and fuel cell performance and resistance could be correlated.

Fig. 2a) shows the temporal evolution of the current density and the HFR. A significantly higher current density for the DMD fuel cell was found compared to the N-112 reference sample. The current densities of the DMD fuel cell steadily 
converged to stable values $\left(1300 \mathrm{~mA} / \mathrm{cm}^{2}\right.$ at $35 \% / 35 \% \mathrm{RH}$, $1100 \mathrm{~mA} / \mathrm{cm}^{2}$ at dry/15\% RH). In contrast, the current density of the N-112 sample showed non-monotonic behaviour. It raised first and then dropped to a constant value. As can be seen in Fig. 2a) this was linked to an increasing HFR value over time for the $\mathrm{N}-112$ sample. The increase of the HFR was a hint for a drying-out of the N-112 membrane. For the DMD sample a very constant evolution of the HFR was observed which was a sign for a continuous and sufficient humidification of the thin membrane. This was confirmed by the measured water profiles across the active fuel cell area which are shown in Fig. $2 c)$ for three times $\left(t_{1}=20 \mathrm{~s}, t_{2}=140 \mathrm{~s}, t_{3}=560 \mathrm{~s}\right)$. The position of the MEAs was depicted with bold lines in the range of about $-0.25 \mathrm{~mm}$ and $0.25 \mathrm{~mm}$. The water content in the DMD fuel cell MEA for the two different states of humidification (dry/15\% RH and 35\%/35\% RH) is comparable over the entire time range, which is in good agreement with the similar stable current density and HFR evolution. Additionally a huge amount of water was found on the anode side in both cases, proving an expressed back diffusion of water from the cathode to the anode side. For the reference sample with N-112 membrane we found a different water formation pattern. In the start-up phase the N-112 fuel cell MEA was sufficiently humidified, as shown for the time $t_{1}$ in Fig. 2c). At $t_{2}$ the water content in the membrane was lowered over time during the operation at $0.5 \mathrm{~V}$ which was well reflected in the starting HFR increase of the $\mathrm{N}-112$ fuel cell (Fig. 2a). At $\mathrm{t}_{3}$ the water content was lower than in the DMD sample, emphasizing the advantageous water management in the DMD fuel cell. Again the HFR evolution was well reflected in the measured water distribution: The measured increase of the HFR from $100 \mathrm{~m} \Omega \mathrm{cm}^{2}$ at $t_{2}$ to about $150 \mathrm{~m} \Omega \mathrm{cm}^{2}$ at $t_{3}$ in the $\mathrm{N}-112$ fuel cell shown in Fig. 2a) came along with a reduction of the water content in the MEA as can be observed in Fig. 2c). The observed water patterns were in good accordance to a neutron imaging study of a fuel cell with identical membrane (Nafion N-112) [21]. The observed accumulation of water on the anode side at $t_{2}=140 \mathrm{~s}$ 
and its decrease at $t_{3}=560 \mathrm{~s}$ for all three samples was likely due to the stoichiometric gas flow (1.5/2.5) which correlates with increasing current density. With raising current density an increasing gas flow facilitates the purging of the flow channels. Furthermore the anode side was fed with pure hydrogen, whereas the cathode side was fed with air $(21 \%$ pure oxygen fraction). This lead to a significantly higher total gas flow on the cathode side, which also favoured a faster water removal in the cathode flow channels.

In a second experiment polarization data was recorded at two different levels of humidification. For each current density step a neutron image was recorded. The polarization curves for the $\mathrm{N}-112$ reference sample under 35\%/35\% RH and the DMD cell under 35\%/35\% RH and dry/15\% RH are shown in Fig. 3a). At a level of humidification lower than $35 \% / 35 \% \mathrm{RH}$ it was impossible to operate the N-112 reference fuel cell. Even under slight loads a too high HFR lead to an immediate breakdown of the N-112 fuel cell voltage. For the DMD fuel cell the maximum power density (not shown) only drops by about $14 \%$ from $650 \mathrm{~mW} / \mathrm{cm}^{2}$ (at $35 \% / 35 \% \mathrm{RH}$ ) to $560 \mathrm{~mW} / \mathrm{cm}^{2}$ (at dry/15\% RH). In comparison, only $200 \mathrm{~mW} / \mathrm{cm}^{2}$ are obtained for the N-112 reference cell at 35\%/35\% RH. An even more significant difference was found in the evolution of the HFR. While the HFR showed only a diminutive increase for the DMD fuel cell when the humidification was reduced from 35\%/35\% $\mathrm{RH}$ to $\mathrm{dry} / 15 \% \mathrm{RH}$, the HFR of the $\mathrm{N}-112$ fuel cell reached already at $35 \% / 35 \% \mathrm{RH}$ values of up to $250 \mathrm{m \Omega} \mathrm{cm} \mathrm{cm}^{2}$. This was about five times higher than the reported resistance values for this Nafion ${ }^{\circledR}$ membrane under fully humidified conditions [5]. The increase of the HFR with increasing current density was a hint for the overcompensation of the water back diffusion by the electroosmotic drag of water molecules from the anode to the cathode side, drying out the N-112 membrane [5,22]. This was in accordance with the results shown in Fig. 2 and previous publications, where the electroosmotic drag was found to dominate the water transport at high current densities [23-25]. This strongly increased HFR was a hint for a reduced proton conductivity of the N-112 membrane due to poor humidification, which was not observed for the thin DMD fuel cell under identical operation conditions.

In Fig. 3b), the water profiles in the DMD fuel cell at dry/15\% $\mathrm{RH}$ and $35 \% / 35 \% \mathrm{RH}$ and the $\mathrm{N}-112$ reference fuel cell were compared at different current densities to link the diverging HFRs to differences in the water management. Regarding the DMD fuel cell only minor differences in the water profile were detected between the two states of humidification over the entire current density range from 0 up to $1500 \mathrm{~mA} / \mathrm{cm}^{2}$. In the supplementary section a video sequence is provided showing the evolution of the neutron images of the DMD fuel cells in both states of humidification with raising current density. The high similarity in spite of different levels of humidification is in excellent agreement with the HFR measurements in which also no significant increase of the ionic resistance was observed. Even though the anode humidification was reduced to zero, we found a nearly identical water evolution over the entire range of the current density. Thus the water on the anode side in Fig. 3b) observed at the current density $j_{2}$ likely originated from back diffusion of generated water from the cathode side. Regarding the N-112 reference cell the increase of the HFR with raising current density was confirmed by a 
reduction of the total water content in the MEA over time. The water content in the MEA was reduced from $j_{1}$ to $j_{2}$ where a lower water content was found compared to the DMD fuel cell MEA.

Supplementary video related to this article can be found at http://dx.doi.org/10.1016/j.ijhydene.2016.05.018.

The results for the DMD sample with $12 \mu \mathrm{m}$ thin membrane are in good agreement with results from industry, where fuel cells with extremely thin membranes (down to $5 \mu \mathrm{m}$ thickness) also showed very low membrane resistances and stable operation under low RH $[26,27]$. However, the membrane resistance is not the only reason for the improved power of DMD fuel cells. As reported in the work of Klingele et al., moreover a reduced charge transfer resistance was found for the DMD fuel cell [1]. This became in particular evident using electrodes with low Pt-loading, where at high current densities a strong deviation was observed between a CCM and $\mathrm{DMD}$ sample in the iR-free representation. In recent literature new concepts with patterned membranes revealed that in spite of identical membrane thickness a modified catalyst-membrane interface can strongly improve the cell performance $[28,29]$. These observations are in good agreement with the observed characteristics of DMD fuel cells.

\section{Conclusion}

A fuel cell with directly deposited membrane was operated at low levels of humidification to investigate its liquid water transport behaviour in the MEA. In situ neutron imaging was performed in order to unravel the robust operation of DMD fuel cells with $12 \mu \mathrm{m}$ thin membranes under dry conditions. The presence of water on the non-humidified anode side proved the facilitated back diffusion of reaction water from the cathode to the anode side. The continuous membrane humidification via back diffusion explained the significantly improved fuel cell performance under dry conditions: Even though the humidification was reduced from 35\%/35\% RH to dry $/ 15 \% \mathrm{RH}$ only a marginal increase of the HFR was measured. In consequence a very similar water distribution was found in the MEA and in the anode and cathode flow channels comparing the two states of humidification. These nearly identical water patterns and similar HFR values despite of two different humidification levels confirmed that in the DMD fuel cell back diffusion compensated the electroosmotic drag even at higher current densities beyond $1200 \mathrm{~mA} / \mathrm{cm}^{2}$ resulting a very stable operation at high current densities. Thus the neutron measurements in this work contributed to a better understanding of the advantageous characteristics of DMD fuel cells.

\section{Acknowledgements}

This work was funded by the German Federal Ministry of Education BMBF within the project "NeuRoTom" (grant number: 05K13VF1). This work is based upon neutron experiments performed at the ANTARES instrument operated by FRM II at 
the Heinz Maier-Leibnitz Zentrum (MLZ), Garching, Germany. The authors would like to thank Matthias Klingele for proofreading the manuscript.

\section{R E F E R E N C E S}

[1] Klingele M, Breitwieser M, Zengerle R, Thiele S. Direct deposition of proton exchange membranes enabling high performance hydrogen fuel cells. J Mater Chem A 2015;3(21):11239-45.

[2] Breitwieser M, Klingele M, Britton B, Holdcroft S, Zengerle R, Thiele S. Improved Pt-utilization efficiency of low Pt-loading PEM fuel cell electrodes using direct membrane deposition. Electrochem Commun 2015;60:168-71.

[3] Büchi FN, Srinivasan S. Operating proton exchange membrane fuel cells without external humidification of the reactant gases fundamental aspects. J Electrochem Soc 1997;144(8):2767-72.

[4] Zhang J, Tang Y, Song C, Cheng X, Zhang J, Wang H. PEM fuel cells operated at $0 \%$ relative humidity in the temperature range of 23-120 C. Electrochim Acta 2007;52(15):5095-101.

[5] Barbir F. PEM fuel cells: theory and practice. San Diego: Elsevier Science; 2012.

[6] Zhu X, Zhang H, Zhang Y, Liang Y, Wang X, Yi B. An ultrathin self-humidifying membrane for PEM fuel cell application: fabrication, characterization, and experimental analysis. J Phys Chem B 2006;110(29):14240-8.

[7] Zhang W, Li MKS, Yue PL, Gao P. Exfoliated Pt-clay/Nafion nanocomposite membrane for self-humidifying polymer electrolyte fuel cells. Langmuir 2008;24(6):2663-70.

[8] Zhang Y, Zhang H, Bi C, Zhu X. An inorganic/organic selfhumidifying composite membranes for proton exchange membrane fuel cell application. Electrochim Acta 2008;53(12):4096-103.

[9] Bunn JR, Penumadu D, Woracek R, Kardjilov N, Hilger A, Manke I, et al. Detection of water with high sensitivity to study polymer electrolyte fuel cell membranes using cold neutrons at high spatial resolution. Appl Phys Lett 2013;102(23):234102.

[10] Iranzo A, Boillat P, Rosa F. Validation of a three dimensional PEM fuel cell CFD model using local liquid water distributions measured with neutron imaging. Int J Hydrogen Energy 2014;39(13):7089-99.

[11] Mishler J, Wang Y, Mukundan R, Spendelow J, Hussey DS, Jacobson DL, et al. Probing the water content in polymer electrolyte fuel cells using neutron radiography. Electrochim Acta 2012;75:1-10.

[12] Mukundan R, Borup RL. Visualising liquid water in PEM fuel cells using neutron imaging. Fuel Cells 2009;9(5):499-505.

[13] Wang HH, Yuan X-Z, Li H. PEM fuel cell diagnostic tools. Boca Raton, FL: CRC Press/Taylor \& Francis; 2012.

[14] Hickner MA, Siegel NP, Chen KS, McBrayer DN, Hussey DS Jacobson DL, et al. Real-time imaging of liquid water in an operating proton exchange membrane fuel cell. J Electrochem Soc 2006;153(5):A902-8. 
[15] Turhan A, Heller K, Brenizer JS, Mench MM. Quantification of liquid water accumulation and distribution in a polymer electrolyte fuel cell using neutron imaging. J Power Sour 2006;160(2):1195-203.

[16] Owejan JP, Gagliardo JJ, Sergi JM, Kandlikar SG, Trabold TA. Water management studies in PEM fuel cells, Part I: Fuel cell design and in situ water distributions. Int J Hydrogen Energy 2009;34(8):3436-44.

[17] Owejan JP, Trabold TA, Jacobson DL, Arif M, Kandlikar SG. Effects of flow field and diffusion layer properties on water accumulation in a PEM fuel cell. Int J Hydrogen Energy 2007;32(17):4489-502.

[18] Iranzo A, Boillat P. Liquid water distribution patterns featuring back-diffusion transport in a PEM fuel cell with neutron imaging. Int J Hydrogen Energy 2014;39(30):17240-5.

[19] Calzada E, Gruenauer F, Mühlbauer M, Schillinger B, Schulz M. New design for the ANTARES-II facility for neutron imaging at FRM II. Nucl Instrum Methods Phys Res Sec A Accel Spectrom Detect Assoc Equip 2009;605(1):50-3.

[20] Butler LG, Schillinger B, Ham K, Dobbins TA, Liu P, Vajo JJ. Neutron imaging of a commercial Li-ion battery during discharge: Application of monochromatic imaging and polychromatic dynamic tomography. Nucl Instrum Methods Phys Res Sec A Accel Spectrom Detect Assoc Equip 2011;651(1):320-8.

[21] Hickner MA, Siegel NP, Chen KS, Hussey DS, Jacobson DL, Arif M. In situ high-resolution neutron radiography of crosssectional liquid water profiles in proton exchange membrane fuel cells. J Electrochem Soc 2008;155(4):B427-34.

[22] Cooper KR, Ramani V, Fenton JM, Kunz HR. Experimental methods and data analyses for polymer electrolyte fuel cells. Southern Pines, NC. 2005.

[23] Nguyen TV, White RE. A water and heat management model for Proton-Exchange-Membrane fuel cells. J Electrochem Soc 1993;140(8):2178-86.

[24] Yan Q, Toghiani H, Wu J. Investigation of water transport through membrane in a PEM fuel cell by water balance experiments. J Power Sour 2006;158(1):316-25.

[25] R. J. Bellows, M. Y. Lin, M. Arif, A. K. Thompson, and D. Jacobson.

[26] Kolde JA, Bahar B, Wilson MS, Zawodzinski TA, Gottesfeld S. Advanced composite polymer electrolyte fuel cell membranes. In: Proton conducting membrane fuel cells I: Proceedings of the first international symposium on proton conducting membrane fuel cells; 1995, October. pp. 95-23.

[27] Kinoshita Shinji, Shimoda Hiroshi. Performances of highly durable PFSA polymer based MEAs at high temperature, low RH and dry-wet conditions 21th-24th. 2008. Progress in MEA, La Grande Motte, France.

[28] Koh JK, Jeon Y, Cho YI, Kim JH, Shul YG. A facile preparation method of surface patterned polymer electrolyte membranes for fuel cell applications. J Mater Chem A 2014;2(23):8652-9.

[29] Jeon Y, Kim DJ, Koh JK, Ji Y, Kim JH, Shul YG. Interfacedesigned membranes with shape-controlled patterns for high-performance polymer electrolyte membrane fuel cells. Sci Rep 2015;5. 